\title{
Issues and Problems of E-Retailing on Consumer Behaviour
}

\author{
Inderjot Kaur, Assistant Professor, Government PG College, Sector 1, Panchkula, Haryana, India.
}

\begin{abstract}
It is admitted fact that with the increase in the use of Internet, a new format of retail has emerged where there is a virtual Retailer and the Consumer who has started purchasing on the Internet without paying physical visit to the store. E-retailing has very firmly established itself as a good alternative to a store based shopping. One can easily see this revolution in the retail market. In this paper, it is attempted to show the picture of various Issues and Problems of E-Retailing on Consumer Behaviour. Many factors influence as well as discourage the consumer to do on line purchasing. These factors have to be carefully studied by the on line retailers so that they can make appropriate marketing strategies to attract more customers to buy on line and also to retain existing ones.
\end{abstract}

Key Words: - Consumer, Retail, E-Retailing, Internet.

\section{INTRODUCTION}

Retailing is considered as a very important part of economy of all the countries because it a link between the retailer and the manufacturers of the goods. Thus retailing is that set of articles which is used to sell a product or a service to the consumers for their use. We are aware that needs and demands of the consumers have been increasing day by day. The Retail Sector is changing very swiftly due to the competition which is entering the market arena besides entering technology in the retailing methods. The sale of goods or services with the help of internet is called Electronic-Retailing or E-Retailing. Now-a-days the people have started the use of internet in bulk resulting growth in the scope of electronic shopping. E-retailing is a shopping on internet and the consumer needs not to pay physical visit at the store.

1) Who is Consumer? Consumer is that person who consumes the goods and uses the service available in the market for his / her end use. The consumer shows inclination towards any product or service if it matches his / her taste, need or pocket.

2) What is Consumer Behaviour? It is study of action of the individual customers in the market and the motives behind those actions. This is dynamic process which keeps changing. It is definitely a complex process which consists of many factors like age, profession, economic background, lifestyle etc. which determine the behaviour of the Consumer.

\section{Difference between E-Retailing and Traditional Retailing}

It is important for a person to know the difference of ERetailing from the Traditional method of Retailing so that the consumer could better understand the benefits of purchasing on line rather than to buy from a store or a shop.
1) Location of Store:-There is no limitation of location in case of online retailers .There is no problem of geographical boundaries as in case of traditional retailing brick and mortar based stores. On line retailers can cater to local, national or international markets and can find customers.

2) Display of goods: - In a brick and mortar store of a traditional store format the customers are able to physically touch and handle the various items for which they are interested in purchasing where as online retailers are forced to display the items through pictures, graphics or text based descriptions of items or products to attract the customers through their Website.

3) Communications with the Retailers: - In a traditional retailing there is a face to face interaction with the retailer and consumer can raise any question about the products or items. On- line retailers have to answer all the possible queries of the prospective buyers through text and graphics.

4) Technology to be used in Retailing: - The technology used to run a store in a traditional format is almost the same and has been in around for years where as online retailers have to keep themselves updated as the technology involved in online retailing is constantly changing.

5) Time available for doing business: - The Traditional retailing is only available for a limited time which is prescribed by the law of state or area or some time based on business. E- Retailing is available 24/7 which means round the clock.

\section{Literature REVIEW}

Arora Jyoti (2013) in her Paper titled 'Prospect of ERetailing in India' has found that the companies should 
create a medium consisting of blogs and discussion Forums for the people where they can give a rating of the quality of the delivered service of the on-line retail and also give suggestions for the improvement. In order to fulfill customer's expectations and needs of the business, the contents should be updated on the Websites. All the issues of security and payments should be sorted out to satisfy the customer's trust. The laws and regulation of the banks should be adjusted for the requirements of electronic fund transfers and the involvement of culture of credit cards. Now a day's the people of India have started E-Retailing or online shopping as their first choice.

Shettar Rajeshwari M. (2016) in her study titled "Emerging Trends of E-Commerce in India: An Empirical Study" has found that in our day to day life, E-Commerce has become very prominent part. In fact for the people living in urban it has become necessity. Due to increase of smart phones and tablets which are based on internet and technology, the way of living, modes of communication and the methods of purchasing etc of people have changed. E-commerce has created new opportunities for education, academics and business. We can see tremendous potential for providing E-business education. It is fact that Ecommerce has made a huge impact on our way to communicate with friends, relatives, on our travelling, way to pass the information and our process to buy or sell products and services.

Mahajan Yogesh D (2017) during his study titled 'A Study of E-retailing: Analyzing the Factors and Perceptions of Indian Millennia's for Online Retailers" has resulted / could find those factors based on which the customers select the on- line Retailers from whom they would like to purchase after selection. The design of the website and the act of responding of a company about the needs of the customers play very important role in the selection of the on-line retailers. The customers also consider the security issues in the transactions and confidentiality of data as very important. They also take in to consideration as to how online Retailers cater to the problems of customers which might have been faced by them during the on-line transactions.

Shrestha Saroj (2018) in his Paper titled "Online Retailing Trend and Future Growth Opportunities in India' studied and found that online retail business would have very good growth in India because the factors like demographics, economy, changing lifestyle, payment systems, increase in internet users \& mobile subscribers etc. are in favour of our country. India has a huge population of young people and after they start working add to the expanding consumer class. The on-line Retailers give a lot of options in the purchase of products and providing on-line service. The payment system is also very secure which motivate the customers to do on-line transactions without any hesitations. Cash on delivery is becoming popular among the customers which are not comfortable with paying online. Indian well established companies have started focus on strong customer service to win trust of the buyers resulting into the lead to repeat buyers, customer's acquisition besides improving profitability. Along with the potential of growth in the on-line retailing, there are also many challenges so the on-line Retailer has to continuously examine the trends and innovations which are happening in online retail in India.

\section{RESEARCH METHODOLOGY}

The study is descriptive in nature and is based on the secondary data which has been collected through secondary source like Text books, Journals, websites and other publication supported by primary data collected through observation techniques. Further I have made sincere efforts to collect data from other sources such as Magazines, the News Papers and other records when the need arose.

\section{Objectives of the Study}

1) To know the impact of E-Retailing on Consumer Behaviour

2) To study the difference between E-Retailing and Traditional Retailing.

3) To understand the reasons of increase in E-Retailing.

4) To examine the challenges and problems due to ERetailing.

\section{Discussion}

\section{Impact of E-retailing on Consumer Behaviour}

The companies which are able to understand how the consumer is going to give response to product features, price, promotion and advertising definitely have an advantage over its competitors. Mostly the companies' research the consumer's buying decisions so that they get answer to questions about what consumers' prefer to buy, why they buy a particular product and which way consumer feels easy to buy a product. There are many factors which influence consumer's behaviour. External factors are from Environmental conditions like demographic, socioeconomic, Technological, cultural and reference group. Internal factors are the Attitudes, learning, perception and motivation of the consumer. In E-Retailing the consumers can research about the products available and purchase the products by sitting at the comfort of their home and at their leisure.

\section{REASONS FOR INCREASE IN E-RETAILING}

1) Internet penetration: - People in the modern society have enough attraction towards the use of internet and customers have access to internet regularly. It is therefore people prefer buying on -line.

2) Option available for payment: - The customers are opting on-line shopping because availability of facility 
of cash on delivery and growth in usage of Debit Card or Credit Card.

3) Variety of products available: - Many products can be offered to the customers on various websites because there is no problem of space constrains as in the physical stores.

4) Saving of lot of time and efforts: - Due to ease in buying the products by spending little time are encouraging the customers to buy online.

5) Market Strategy of giving heavy discount: - The ERetailers have started to give heavy discount to the consumer which has resulted in growth of purchase online.

6) Better comparison of Products: - The process of comparing and buying different brands becomes easy for the customers by checking different websites sitting at their homes.

\section{Challenges for E-Retailing}

1) Issues regarding Security:-While using the E-Retailing method some of the consumers are concerned about their personal data which is being provided during the on-line transactions. There is still some lack of trust and certain privacy concern which has been preventing customers to make on-line purchasing.

2) Touch and feel experience of products: - Some families prefer to buy the products personally. Shopping is also like a family outing for some people. So the idea of buying goods online on a computer does not excite them.

3) Retention of customer: - Some people make purchases online once just out of curiosity. Therefore repeat purchase is not likely, so question of customer retention does not arise.

4) Authenticity of the Products: - Customers sometimes feel that the product they purchase online is not as expected by them. When they receive the delivery of product they feel that the product is not as real as they have seen in the picture of the product on Website.

\section{CONCLUSION}

With the rapid growth and penetration of internet, the overall trend for on-line purchasing is very optimistic. Among the various reasons which help the E-Retailing to become popular can be the option of availability of facility of cash on delivery and growth in usage of Debit Card or Credit Card, a wide range of Merchandise on many Websites and tracking of shipments on line besides the reach of internet at cheaper costs. However the E-Retailers should try their best to encourage the reluctant customers to accept the internet as a new way of shopping and try to win their trust by making them purchase through the method of
E-Retailing. The On line Retailers should direct their field staff to research and identify about the preference of the customers and adjust the contents at the websites accordingly. The customers should be provided the same quality of products as they have ordered so that they may not feel that the E-Retailers have cheated them. The consumer behaviour will definitely turn positive towards the E-Retailers if they assist the consumers in overcoming their fear around security and feeling safe with on-line purchasing and avoiding the delay in delivery of products to the customers. If these problems are solved then the online retailing business will definitely grow towards bright future.

\section{REFERENCES}

[1] Arora Jyoti (2013) Prospect of E-Retailing In India ,IOSR Journal of Computer Engineering (IOSR-JCE) e-ISSN: 22780661, p- ISSN: 2278-8727 Volume 10, Issue 3 (Mar. - Apr. 2013), PP 11-15 www.iosrjournals.org www.iosrjournals.org Retrieved on 20 March 2020 from https://pdfs.semanticscholar.org/b01a/63594b035796ef054e3 c10cdedaa7d5a40f2.pdf

[2] Mahajan Yogesh D (2017) A Study of E-retailing: Analysing the Factors and Perceptions of Indian Millennials for Online Retailers, IMR (Indira Management Review) Volume XI, Issue I, July, 2017 Retrievedon 20 March 2020 from http://indiraisbs.ac.in/IMR/wp-content/uploads/2017/11/Dr.Yogesh-D-Mahajan.pdf

[3] Shettar Rajeshwari M. (2016) Emerging trends of ECommerce in India, International Journal of Business and Management Invention ISSN (Online): 2319 - 8028, ISSN (Print): 2319 - 801X www.ijbmi.org || Volume 5 Issue 9 || September. 2016 || PP-25-31 www.ijbmi.org Retrieved on 18 March 2020 from http://www.ijbmi.org/papers/Vol(5)9/E05902531.pdf

[4] Shrestha Saroj (2018), Online Retailing Trend and Future Growth Opportunities in India Journal of Economics, Business and Management, Vol. 6, No. 3, August 2018 Retrieved on 18 March 2020 from http://www.joebm.com/vol6/561-ME0027.pdf

[5] Hargrave Marshall (2019,4 September) Electronic Retailing (E-tailing) Business Essentials Retrieved on 18 March 2020 from https://www.investopedia.com/terms/e/electronicretailing-e-tailing.asp

[6] Joshi Priyanka, Upadhay Hemant (2014 January), ERetailing in India Despite issues, Customers satisfied with top retailer Consumer Voice Retrieved on 22 March 2020 from http://www.fcamin.nic.in/consumer/WriteReadData/eRetailingindia.pdf

[7] E-Commerce in India (2020,!4 March) Retrieved on 22 March $2020 \quad$ from https://en.wikipedia.org/wiki/E-commerce_in_India

[8] Jayakrishnan S.(2015,10 April) E-Retailing in India: Opportunities and Challenges International Journal of Research in Finance and Marketing, Vol. 5, Issue 3 Retrieved on 29 March ,2020 from https://papers.ssrn.com/sol3/papers.cfm?abstract_id=2592413 
[9] Dwivedi Manish, Kumawat Mahesh,Verma Sanjeev (2012)Online Retailing in India: Opportunities and Challenges I.J.E.M.S., VOL.3(3) 2012: 336-338 ISSN 2229600X 336 Retrieved on22 March 2020 from http://scienceandnature.org/IJEMS-Vol3(3)July2012/IJEMS_V3(3)12.pdf

[10] Rasool Adil, Rajmohan .P (2015) An Empirical study on eRetailing in India IOSR Journal of Business and Management (IOSR-JBM)e-ISSN: 2278-487X, p-ISSN: 2319-7668. Volume 17, Issue 3.Ver. III (Mar. 2015), PP 3137www.iosrjournals.orgDOI: $\quad$ 10.9790/487X-17333137 www.iosrjournals.org 31,Retrieved on 22 March 2020 from http://www.iosrjournals.org/iosr-jbm/papers/Vol17-

issue3/Version-3/G017333137.pdf

[11] Kanchan Upasana ,Kumar Naveen,Gupta Abhishek (2015) A study of online behavior of customers in India ICTACT JOURNAL ON MANAGEMENT STUDIES, AUGUST 2015, VOLUME: 01, ISSUE: 03 DOI: 10.21917/ijms.2015.0019, Retrieved on 19 March 2020 from http://ictactjournals.in/paper/IJMS_V1_I3_Paper_4_136_142 .pdf

[12] Goyal Aishwarya , (2015) Rising Trends of Online Shopping In India Biz and Bytes (Vol. 6. Issue: 2, 2015) E-ISSN: 0976 0458, Print ISSN: 2320 897X, Retrieved on 22 March 2020 from http://cbsmohali.org/img/Rising\%20trends\%20of\%200nline $\% 20$ Shopping\%20In\%20India.pdf

[13] SanwalTanushree, Avasthi Sandhya , Saxena Shikha,(2016) E-Commerce and its sway on the minds of young ,International Journal of Scientific and Research Publications, Volume 6, Issue 3, March 2016 112ISSN 22503153www.ijsrp.orggeneration, Retrieved on 24 March 2020 from http://www.ijsrp.org/research-paper-0316/ijsrpp5120.pdf 